\title{
A Case of Nasal Septal Abscess Caused by Combined Bacterial and Fungal Infection in the Immunocompromised Patient
}

\author{
Il-Kwon Cho and Young-Jun Chung \\ Department of Otorhinolaryngology-Head and Neck Surgery, Dankook University College of Medicine, Cheonan, Korea
}

\section{면역 저하 환자에서 세균과 진균 감염에 의해 발현된 비중격 농양}

\author{
조 일 권·정 영 준 \\ 단국대학교 의과대학 이비인후-두경부외과학교실
}

\author{
Received February 22, 2012 \\ Revised April 24, 2012 \\ Accepted April 27, 2012 \\ Address for correspondence \\ Young-Jun Chung, MD \\ Department of Otorhinolaryngology- \\ Head and Neck Surgery, \\ Dankook University \\ College of Medicine, \\ 201 Manghyang-ro, \\ Cheonan 330-715, Korea \\ Tel +82-41-550-3974 \\ Fax +82-41-550-1090 \\ E-mail docjung@paran.com
}

\begin{abstract}
Nasal septal abscess (NSA) occurs more commonly after minor trauma and subsequent bacterial infection. However, it rarely occurs without trauma and can be associated with poor immunity. In the immunocompromised patient, NSA can occur due to fungal as well as bacterial infection; cases caused by fungal infection have been rarely reported. We experienced a case of NSA caused by combined fungal and bacterial infection without trauma in a patient with poorly-controlled diabetes mellitus. He underwent incision and drainage. Organism cultured from NSA was Staphylococcus epidermidis. Pathologic examination identified granulomatous inflammation in the septal cartilage and septate, branching fungal hyphae that had invaded the cartilage. He was treated by adequate blood glucose control and antibiotics coverage without antifungal medications. His symptom was improved despite the antifungal agent was not used. Therefore, we present this case with a brief review of the disease entity and discuss the necessity of antifungal treatment in this case.
\end{abstract}

Korean J Otorhinolaryngol-Head Neck Surg 2012;55:378-81

Key Words Nasal septum · Abscess · Fungi.

\section{서 론}

비중격 농양은 비중격 연골부와 연골막 또는 비중격 골부와 골막 사이에 농성 분비물이 고이는 드문 질환이다. ${ }^{1)}$ 대부분은 외상에 의해 발생하지만, 드물게 외상 없이도 비전정염, 급성 부 비동염, 치성감염, 면역 저하 등의 선행 병변에 의해서도 발생 할 수 있다. ${ }^{2-4)}$ 세균이 원인균인 경우가 대부분이지만, 진균에 의해서 비중격 농양이 발병한 증례들도 드물게 보고된다. ${ }^{5-8)}$

비중격 농양을 일으킨 원인균 동정에는 수술 후 수일이 소 요되기 때문에, 원인균이 확진되기까지는 경험적인 항생제를 정맥으로 투여하면서 호전 및 재발 여부를 관찰하는 것이 술 후 일반적인 치료법이다. 하지만, 잘 조절되지 않은 당뇨와 같은 면 역능의 저하가 동반된 환자에서 술 후에 항생제 치료와 철저한
당 조절만으로 재발 없이 호전되고 있는데, 술 후 균 배양 및 조 직 검사에서 세균 감염뿐 아니라 조직 내 만성 침습성 진균증 이 추가로 진단되는 경우에 전신적 항진균제를 반드시 추가적 으로 사용해야 하는가에 대해선 이견이 있을 수 있다." 최근 저자들은 혈당이 잘 조절되지 않았던 2형 당뇨 환자에서 세균 및 만성 침습성 진균증이 동반되어 발생한 비중격 농양 증례를 통해 위와 같은 경험을 하였다. 즉각적인 절개 배농술을 시행 한 후 항생제 치료와 철저한 당 조절로 재발 없이 호전되던 중 에, 비중격 연골에서 시행한 조직검사에서 만성 육아종성 염증 과 연골을 침습한 진균 소견이 관찰되어 추가적으로 만성 침습 성 진균 감염으로 진단되었다. 저자들은 이 환자를 전신적 항 진균제 사용 없이 술 후 철저한 혈당 조절과 항생제 치료만으 로 재발 없이 치료하였기에, 본 증례와 같은 경우에서 전신적 항 
진균제 사용이 반드시 필요한가에 대해 문헌고찰과 함께 보고 하는 바이다.

\section{증 례}

52세 남자 환자가 약 2달 전부터 간헐적인 양측 코막힘과 화 농성 비루가 발생하여 개인병원에서 부비동염으로 진단받고 치 료하던 중, 지속적인 양측 코막힘과 비내 통증이 1달 전부터 지 속되어 외래를 방문하였다. 환자는 당뇨로 약 5 6년 전부터 경구 혈당 강하제(Glimepiride $1 \mathrm{mg}$, Metformin $500 \mathrm{mg}$ )를 복용 중 이었으며, 외상의 과거력은 없었다. 내원시 시행한 비내시경 검 사에서 양측 비중격의 미부에 비강을 가득 채운 종창 소견이 관 찰되었고, 외비는 안장코의 형태를 보였다(Fig. 1). 비인두 부위에 서 후비루의 소견은 없었다. 전신적인 발열 및 오한은 없었고, 내 원 당일 시행한 혈당 수치는 $537 \mathrm{mg} / \mathrm{dL}$, 요검사에서 glucose $4+, \mathrm{HbAlc}$ 는 $12.8 \%$ 로 측정되었다. 혈액검사에서 백혈구 수치는 $7300 \mathrm{~mm}^{3}$ (호중구 58.8\%)였으며, 그 외 특이소견은 없었다.

비중격 농양으로 진단하고, 내원 당일 국소 마취 하에 절개 배농술을 시행하였다. 좌측 비중격 미부에 반관통 절개를 시행 하여 약 $6 \mathrm{~mL}$ 의 농성 분비물을 배농한 후, 농성 분비물은 세 균 배양 및 그람 염색을 시행하였다. 수술 소견 상 비중격의 골 부는 잘 보존된 반면, 대부분의 비중격 연골은 괴사된 양상이 었다. 특히, 잔존한 비중격 연골의 경계면과 연골막이 술자가 기 존에 경험했던 비중격 농양 증례들에 비해 더 지저분한 양상이 었다. 따라서, 당이 잘 조절되지 않았던 환자에서 비중격의 잔 존한 연골부와 연골막 등이 더 지저분한 소견을 고려하여 진균 에 의한 비중격 농양과 감별을 위해 연골의 잔존부에서 조직검 사를 시행하고, 괴사된 주변 연골 조직을 추가적으로 제거하였 다. 수술 중 시행한 비내시경 검사에서 화농성 비루 등의 비부 비동염에 합당한 소견은 관찰되지 않았으며, 비중격에 관통봉 합을 시행한 후 거즈로 양측 비강을 충전하였다. 술 후 항생제 (Flomoxef sodium 500 mg twice daily, Cindamycin 300 mg twice daily)를 정맥으로 투여하였고, 술 후 3일째 비강 내 충 전물을 제거하였다. 입원 기간 중 비중격 농양이 재발되지 않 아 수술 후 5일째 경구용 항생제(Cefuroxime $250 \mathrm{mg}$ twice daily, Clindamycin $300 \mathrm{mg}$ three times daily)로 교체하여 퇴원 하였다. 입원기간 중에는 내과와 협진하여 당뇨식 $(1400 \mathrm{kcal})$ 과 $\mathrm{NPH}$ 와 RI를 아침, 저녁으로 병용 투여하면서 혈당을 식전 130 $\mathrm{mg} / \mathrm{dL}$ 이하, 식후 $200 \mathrm{mg} / \mathrm{dL}$ 이하로 조절하였다. 당뇨 교육 을 받고, 인슐린을 처방 받은 후 퇴원하였다.

퇴원 후 1 주째 외래 방문시 비중격 농양의 재발 소견은 관찰 되지 않았고, 배양 검사에서 Staphylococcus epidermidis가 동 정되었다. 잔존한 비중격 연골부에서 시행한 병리조직검사
에서 만성육아종성 염증과 진균의 연골 침습 소견이 관찰되어 만성 침습성 진균증으로 추가 확진되었다. 염증성 기질 및 다핵 거대세포 내에는 곰팡이 균사가 다수 관찰되었고, 곰팡이 균사 는 periodic acid-Schiff 염색과 Gomori methenamine silver 염색에서 격막과 예각 가지가 뚜렷이 보이는 Aspergillus종으 로 진단되었다(Fig. 2). 비중격 농양이 술 후 재발 없이 소실된 점과 당이 조절이 잘 되고 있는 점을 감안하여 항진균제를 추가 하지 않고, cefuroxime(250 mg twice daily)을 2주 더 처방하 였다. 외래에서 1 주 간격으로 경과 관찰하기로 하고, 추후 비 중격 농양이 재발하는 경우에는 재수술 및 항진균제 투여의 가 능성을 환자에게 충분히 설명한 후 동의를 구하였다.

술 후 한 달간은 1 주 간격으로, 그 다음 두 달간은 2주 간격 으로 경과를 관찰하였으며, 이후에는 1 개월마다 정기적으로 외래에서 추적 관찰하였다. 현재 술 후 약 1 년이 경과된 시점에 서 증상의 악화나 비중격 농양의 재발 소견은 관찰되지 않고 있 다(Fig. 3). 당뇨는 HbAlc가 술 후 2개월째부터 6.2 7.3\%로 측 정되며, 내과 외래를 정기적으로 방문하면서 치료 관찰 중이다.

\section{고 찰}

비중격 농양이 의심되면 즉각적인 절개 배농술과 함께 경 험적인 항생제 치료를 시작해야 하며, 흡입된 농양은 그람 염 색 및 배양검사를 시행하여 감수성 있는 항생제 치료를 해야 한다.1,10,11) 가장 흔히 검출되는 세균은 Staphylococcus aureus 이며, Streptococcus pneumonia, Staphylococcus epidermidis, Hemophilus influenza 및 혐기성 세균 등이 검출되기도 한다.4,10) 본 증례에서도 Staphylococcus epidermidis가 검출되었으며, 술 후 경험적 항생제 요법을 시행하였고, 균 배양 결과 및 항생 제 감수성 결과가 나온 후에는 이에 맞는 경구용 항생제로 치 료하였다. S. epidermidis는 비전정부의 피부 및 점막에 존재하 는 균이지만, 절개 전 주사기로 흡인한 농양과 절개 후 비중격 내부에서 획득한 농양에서 시행한 균배양 검사에서 모두 $S$. epidermidis 가 검출되었고 기존 문헌에도 흔한 원인균으로 보 고되어 검체의 오염 가능성은 희박하다고 판단된다. ${ }^{4,12)}$

비중격 농양의 원인균은 세균이 대부분이지만, 문헌 고찰 상 진균이 원인균인 경우도 4예가 보고된 바 있다. ${ }^{5-8)}$ 이들은 신장 이식, 크론병, 백혈병, 림프종 등으로 면역 억제요법이나 항암 치료 중이던 환자들에서 외상없이 발생한 비중격 농양으로, 절 개 배농술과 항생제로 입원 치료 중에 재발되어 추가 검사에서 진균이 원인균으로 확진되어 전신적 항진균제로 치료한 증례들 이다. ${ }^{6-8)}$ 본 증례가 이들과 다른 점은 조절되지 않은 당뇨로 인 해 면역능이 저하된 환자에서 진균과 세균이 공존하여 비중격 농양을 야기한 점과 수술 후 조직 검사에서 만성 침습성 진균 

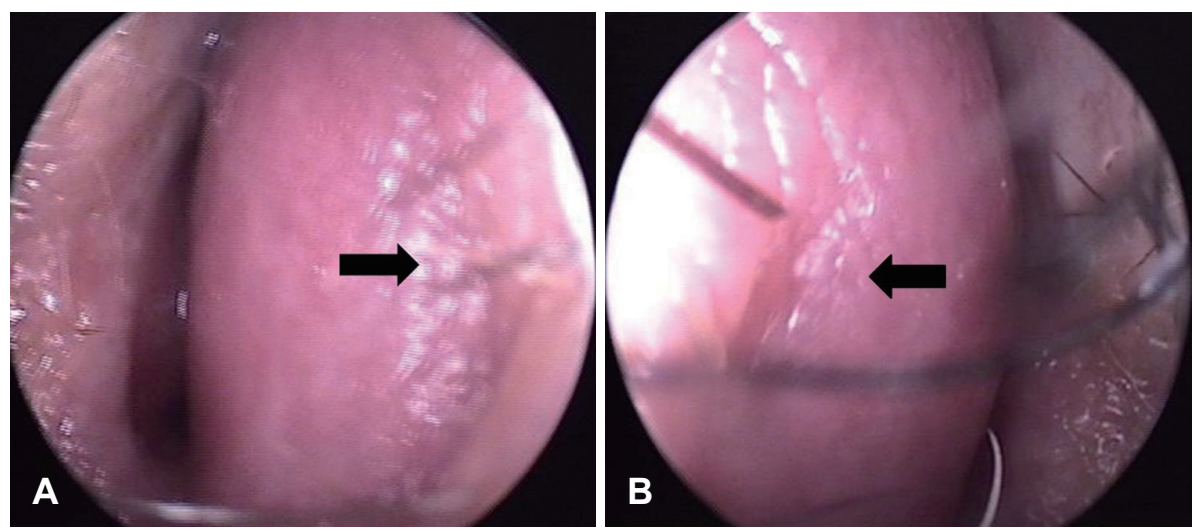

Fig. 1. Preoperative endoscopic findings. Both nasal cavities are filled up with red-colored bulging septum (black arrows). Right nasal cavity (A). Left nasal cavity (B).
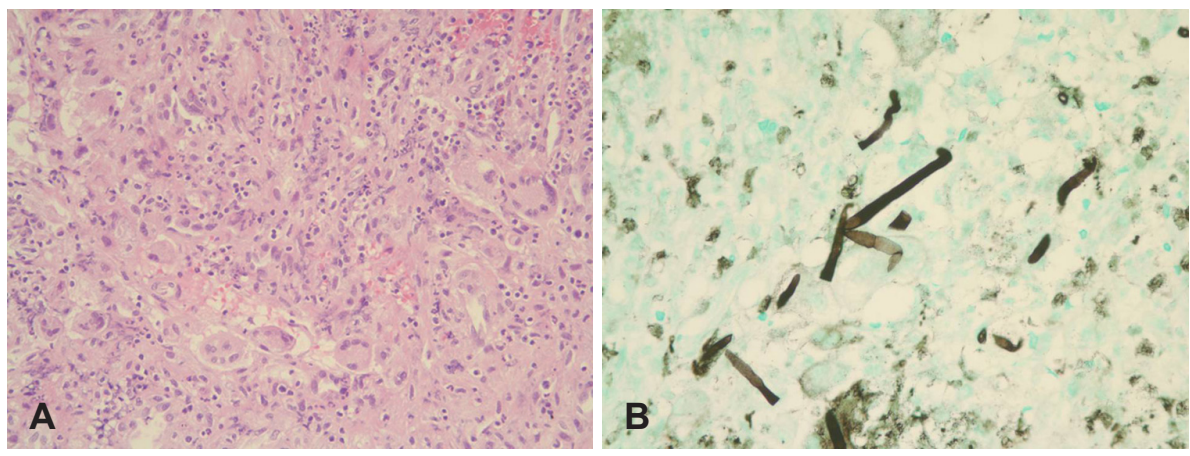

Fig. 2. Histologic findings. Biopsy specimen reveals chronic granulomatous inflammation showing many multinucleated giant cells (hematoxyllin-eosin stain, $\times 200)(A)$. Many septated fungal hyphae suggestive of Aspergillus species are identified (Gomori methanamine silver stain,
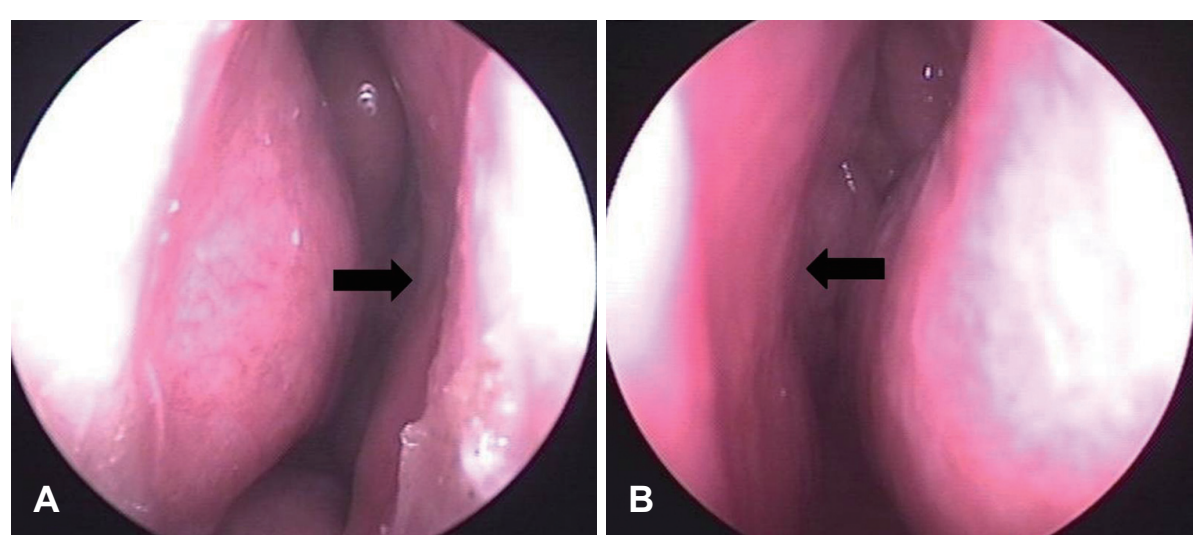
$\times 400)(B)$.

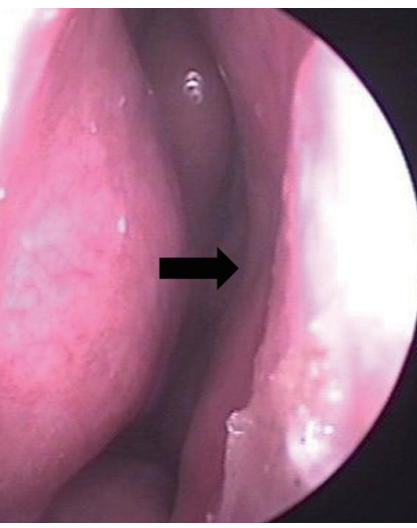

감염이 추가 진단되기 전까지 항생제 치료만으로 입원 중 재발

제 요법을 추천하지만, 전신적 항진균제 요법에 따르는 부작용 없이 호전된 점이다. 실제 수술 후 비중격 농양을 일으킨 원인 균 동정에는 수일이 소요되기 때문에, 원인균이 확인되기까지 는 경험적인 항생제 요법을 시행하면서 재발 여부를 관찰하는 것이 일반적인 치료법이다. 하지만, 본 증례와 같이 수술과 항 생제 치료로 호전되어 퇴원한 다음, 외래에서 확인한 조직검사 결과에서 만성 침습성 진균증이 추가 확진된 경우에 전신적 항 진균제를 추가적으로 반드시 사용해야 하는가에 대해선 이견 이 있다." 급성 전격성 진균성 부비동염인 경우에는 광범위한 조직절제술과 전신적 항진균제 요법을 병행하는 것이 치료방침 이라는 것에 대해 이견이 없다. 하지만, 만성 침습성 진균성 부 비동염의 경우에는 대부분의 저자들이 수술과 전신적 항진균

Fig. 3. Endoscopic finding at 4 months postoperatively. The nasal septum (black arrows) is not bulging and healed well. Right nasal cavity (A). Left nasal cavity (B).

및 문제점들을 고려해야 하기 때문에 치료 원칙에 대해선 이견 이 있다.") deShazo 등 ${ }^{13)}$ 은 만성 침습성 진균성 부비동염 환자 에서 간혹 급성 전격성 진균성 부비동염의 양상을 보이는 경우 가 존재하는데, 이런 경우에 급성 전격성 진균성 부비동염에 준 해 치료해야 한다고 하였다. Morpeth 등 ${ }^{14}$ 은 특히 육아종성 침습성 진균성 부비동염의 양상을 보이는 환자들에서는 전신 적 항진균제 사용 없이 제한적 외과적 절제술을 추천하였고 필요하면 반복적으로 시행하여 치료할 수 있다고 보고하였 다. 또한, Busaba 등9이 보고한 만성 침습성 진균성 부비동염 증례에서도 수술 후 조직검사에서 진균의 침습이 국소적이고 골조직이나 혈관을 침범하지 않았기 때문에, 전신적 항진균제 
를 사용하지 않았으며 5년 동안 재발 없이 관찰 중이라고 보 고하였다.

본 증례에서 만성 침습성 진균증으로 추가 진단되었음에도 전신적 항진균제 사용 없이 호전된 이유로 만성 침습성 진균 감 염이 서서히 비중격을 침범한 상황에서 급성 세균 감염으로 비중격 농양이 발생했을 가능성을 생각할 수 있다. 급성 세균 감염은 절개 배농술과 항생제로 완치되었고, 진균에 의해 침범 된 비연골부는 수술시 괴사된 연골 주변부를 추가 제거하여 재 발 없이 호전된 것으로 판단된다. 본 증례의 조직검사에서도 육아종성 만성 침습성 진균증 소견을 보였기 때문에, 기존 문 헌 보고와 같이 제한적인 수술적 절제술이 효과적이었다고 추정된다. ${ }^{9)}$ 기저질환 측면에서도 침습성 진균증에 의해 비중 격 농양이 발생한 기존 증례들은 신장이식, 백혈병 및 크론병 에 의해 지속적인 면역 억제요법이나 항암 치료로 면역능이 회복이 어려웠던 반면, 본 증례는 조절되지 않은 당뇨로 인해 면역능의 저하된 경우이기 때문에 수술 및 항생제 치료와 철 저한 당 조절과 당뇨 교육 등을 통한 기저질환의 교정이 가능 하여 항진균제 사용 없이 호전되었을 것으로 추정된다. ${ }^{6-8)}$

본 증례와 같이 비중격 농양으로 절개 배농술과 경험적 항생 제 치료로 재발 없이 호전되어 퇴원한 후, 외래에서 확인한 검 사에서 세균 동정뿐만 아니라 만성 침습성 진균증이 추가 진 단되는 경우라도 재발 소견이 보이지 않으면 항진균제를 사용 하지 않고 주기적으로 경과 관찰하는 방법이 하나의 선택적 치 료법이 될 수 있다고 생각된다. 결론적으로, 면역 저하 환자에 서 만성 침습성 진균증이 동반된 경우라도 면역능의 저하가 회 복 가능하고 병변의 범위가 제한적인 경우에는 전신적 항진균 제의 사용에 따른 신독성과 전해질 이상과 같은 전신 부작용 도 고려하여 환자의 면역 상태 및 치료 경과에 따라 맞춤 치료
를 하는 것이 치료법이 될 수 있다고 판단된다.

\section{REFERENCES}

1) Ambrus PS, Eavey RD, Baker AS, Wilson WR, Kelly JH. Management of nasal septal abscess. Laryngoscope 1981;91(4):575-82.

2) da Silva M, Helman J, Eliachar I, Joachims HZ. Nasal septal abscess of dental origin. Arch Otolaryngol 1982;108(6):380-1.

3) Dispenza C, Saraniti C, Dispenza F, Caramanna C, Salzano FA. Management of nasal septal abscess in childhood: our experience. Int J Pediatr Otorhinolaryngol 2004;68(11):1417-21.

4) Pang KP, Sethi DS. Nasal septal abscess: an unusual complication of acute spheno-ethmoiditis. J Laryngol Otol 2002;116(7):543-5.

5) Debnam JM, Gillenwater AM, Ginsberg LE. Nasal septal abscess in patients with immunosuppression. AJNR Am J Neuroradiol 2007; 28(10):1878-9.

6) Dornbusch HJ, Buzina W, Summerbell RC, Lass-Flörl C, Lackner H, Schwinger W, et al. Fusarium verticillioides abscess of the nasal septum in an immunosuppressed child: case report and identification of the morphologically atypical fungal strain. J Clin Microbiol 2005;43 (4):1998-2001.

7) Jeong JH, Kim HO, Lee YS, Chung JH. A case of fungal nasal septal abscess in the immnocompromiased patient. Korean J OtolaryngolHead Neck Surg 2008;51(11):1061-4.

8) Walker R, Gardner L, Sindwani R. Fungal nasal septal abscess in the immunocompromised patient. Otolaryngol Head Neck Surg 2007;136 (3):506-7.

9) Busaba NY, Colden DG, Faquin WC, Salman SD. Chronic invasive fungal sinusitis: a report of two atypical cases. Ear Nose Throat J 2002;81(7):462-6.

10) Lopez MA, Liu JH, Hartley BE, Myer CM. Septal hematoma and abscess after nasal trauma. Clin Pediatr (Phila) 2000;39(10):609-10.

11) Shah SB, Murr AH, Lee KC. Nontraumatic nasal septal abscesses in the immunocompromised: etiology, recognition, treatment, and sequelae. Am J Rhinol 2000;14(1):39-43.

12) Huang PH, Chiang YC, Yang TH, Chao PZ, Lee FP. Nasal septal abscess. Otolaryngol Head Neck Surg 2006;135(2):335-6.

13) deShazo RD, Chapin K, Swain RE. Fungal sinusitis. N Engl J Med 1997;337(4):254-9.

14) Morpeth JF, Rupp NT, Dolen WK, Bent JP, Kuhn FA. Fungal sinusitis: an update. Ann Allergy Asthma Immunol 1996;76(2):128-39; quiz 139-40. 